\title{
A new genus and a new species of the tribe Haplotropidini Sergeev (Orthoptera: Acridoidea, Pamphagidae, Pamphaginae) with a key to the three genera of the tribe from China
}

\author{
Xiang-Chu Yin, Zhan Yin \& Cheng-Quan Cao
}

\begin{abstract}
Yin, X. C., Yin, Z. \& Cao, C. Q. 2017: Anew genus and a new species of the tribe Haplotropidini Sergeev (Orthoptera: Acridoidea, Pamphagidae, Pamphaginae) with a key to the three genera of the tribe from China. - Entomol. Fennica 28: $16-20$.
\end{abstract}

This paper reports a new genus and a species of the tribe Haplotropidini Sergeev, 1995, i.e. Sulcohumpacris Yin, Yin et Cao gen. n. and Sulcohumpacris hebeiensis Yin, Yin et Cao sp. n. from Hebei Province, China. The new genus is similar to Humphaplotropis Xiao, Yin et Yin, 2013, but differs from the latter by the hump-formed pronotum along the median keel being deeply cut by hind sulcus and hence divided in two waves in lateral view, the anterior margin being acutely angular in the middle, the apex not reaching the hind margin of the eyes, the frontal ridge being widened at the median ocellus, and the abdomen having large teeth along the median keel in lateral view. A key to the three genera of this Chinese tribe is given. The type specimens are deposited in the Museum of Hebei University, Baoding, China.

X. C. Yin, The Key Laboratory of Zoological Systematics and Application, College of Life Sciences, Hebei University, Baoding, Hebei 071002, China, and Northwest Plateau Institute of Biology, Chinese Academy of Sciences, Xining 810008, China; E-mail: yxch@hbu.edu.cn

Z. Yin, The Key Laboratory of Zoological Systematics and Application, College of Life Sciences, Hebei University, Baoding, Hebei 071002, China

C. Q. Cao, College of Life Science, Leshan Normal University, Leshan 614004, China

Received 21 June 2015, accepted 13 October 2016

\section{Introduction}

The subfamily Pamphaginae (Orthoptera: Acridoidea, Pamphagidae) contains 5 tribes, 45 genera and 250 species in the world. Among them the tribe Haplotropidini Sergeev, 1995 contains only two genera, Haplotropis Saussure, 1888 and Humphaplotropis Xiao, Yin et Yin, 2013, which are found in China (Saussure 1888, Bei-Bienko \&
Mistshenko 1951, Otte 1994, Xia et al. 1994, Yin et al. 1996, Zhang et al. 2003, 2006, Storozhenko \& Paik 2011, Zhang et al. 2011, Li et al. 2013, Xiao et al. 2013, Li et al. 2014, Eades et al. 2015, Dong et al. 2015, Zhi et al. 2015).

When examining specimens of grasshoppers preserved in the Museum of Hebei University, we discovered a new genus and a species of the tribe Haplotropidini from the Hebei province, China. 
The descriptions of this new genus and species are given below. A key to three genera of the tribe Haplotripidini from China is also given.

\section{Materials and methods}

Descriptions and measurements were made under a stereomicroscope (Leica M 205 A, LAS V 4.0). The figures were drawn with a Canon 5D Mark II and Adobe Photoshop version 9.0 software.

All specimens studied are deposited in the Museum of Hebei University, Baoding, China [MHBU].

\section{Taxonomy}

\subsection{Genus Sulcohumpacris Yin, Yin et Cao gen. $n$.}

Type-species. Sulcohumpacris hebeiensis Yin, Yin et Cao sp. n., here designated.

Diagnosis. The differences of the new genus from other genera of the tribe are given in a key below.

Description. Antennae filiform. Frontal ridge widened at median ocellus. Median keel of pronotum raised, arc-like, deeply cut by hind sulcus; lateral keels developed; anterior margin of pronotum acute angular in middle. Prosternum collarlike with a thin edge, without tubercles or lobes. Tegmina short, oval, lateral, extending over hind margin of first abdominal tergite. Mid tibia without teeth or tubercles. Hind femora robust, lower basal lobe longer than upper one, upper keel smooth. Hind tibia with 8-9 spines on inner side and 9-11 spines on outer side, external apical spine present. Tympanum large, oval. Krauss' organ washboard-like. Abdomen with large teeth along median keel in lateral view. Epiproct with longitudinal groove in middle. Cerci conical, almost reaching apex of epiproct. Subgenital plate triangle, apex not acute. Epiphallus bridge-like, lophi with numerous tubercules, anocorae distinctly oblique incurved, posterior projections distinctly shorter than median projection.

Composition. The genus consists of the type species only.

Etymology. The new genus Sulco-hump-acris is derived from the grasshopper (-acris) with median keel of pronotum as hump (-hump-) and cut by hind sulcus (culco-) in Latin.

\subsection{Sulcohumpacris hebeiensis Yin, Yin et Cao sp. n. (Fig. 1)}

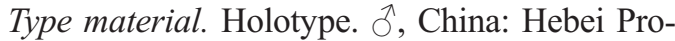
vince, Xingtai, Yegoumen Water Reservoir (37 $\left.13^{\circ} \mathrm{N}, 114^{\circ} 1^{\prime} \mathrm{E}\right), 398 \mathrm{~m}$ a.s.1., 3.VII.2007, Cao Cheng-Quan and Ge Yan-Zhen leg. Deposited in MHBU. Paratype. + , the same data as for holotype. Deposited in MHBU.

Description. Male (holotype) (Fig. 1a-d, f). Body medium in size. Head shorter than length of pronotum. Face slightly oblique in profile, frontal ridge with longitudinal sulcus, widened at median ocellus. Antennae filiform, with 22 segments, not reaching posterior margin of pronotum. Eyes globose, longitudinal diameter 1.3 times horizontal diameter and 1.5 times subocular furrow. Anterior margin of pronotum reaching hind margin of eyes; metazona 1.9 times shorter than prozona. Length of tegmen 2.3 times width. Hind femur robust, 3.4 times as long as its maximum width, apex of lower knee lobes rounded. Hind tibia with 8 spines on inner side and 9 spines on outer side. Krauss' organ 1.4 times as wide as long. Abdomen with large teeth along median keel in lateral view. Epiproct with longitudinal groove in middle. Cercus conical, almost reaching the apex of epiproct; apical half of cercus gently tapering. Subgenital plate triangle, apex not acute. Epiphallus as in Fig. 1d.

Female (Fig. 1e). Similar to male, but larger and robust. Eyes small, longitudinal diameter almost equal subocular furrow. Metazona 2.1 times shorter than prozona. Tegmina not reaching hind margin of first abdominal tergite, length is 1.8 times its width. Hind tibia with 9 spines on inner side and 11 spines on outer side. Valves of ovipositor slender and slightly curved, with pointed apex.

Colouration. Body yellowish-brown. Eyes brown. Antennae yellowish-brown, apical part dark. Hind femur yellowish-brown, with two black bands on upper side. Hind tibia and tarsus yellowish-brown, upper and inner side blue. Abdomen yellowish-brown, with a dark stripe on 


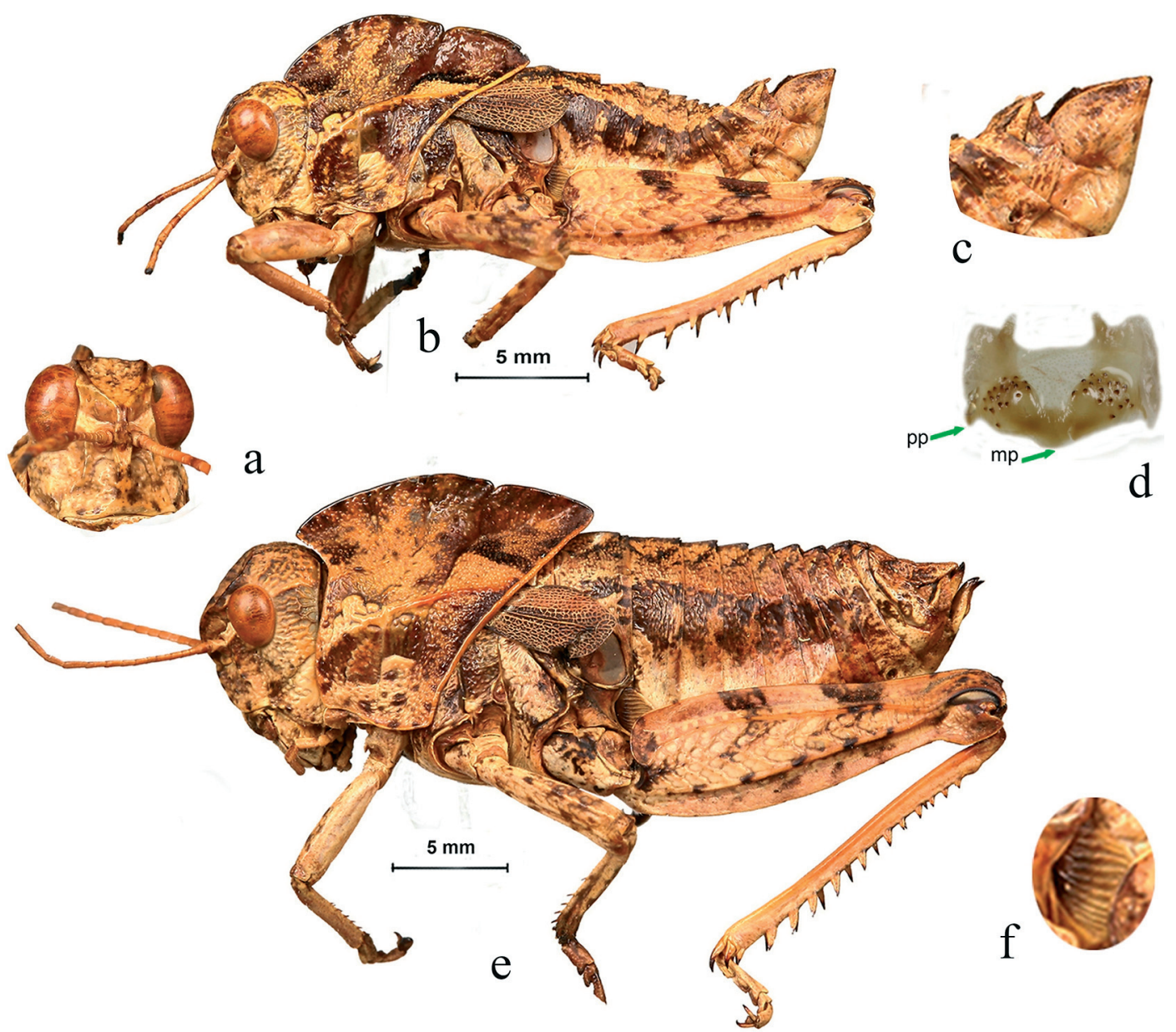

Fig. 1. Sulcohumpacris hebeiensis Yin, Yin et Cao sp. n. (holotype ${ }^{\lambda}$ and paratype + ). - a. Head, $\widehat{\partial}$, frontal view. - b. Body, $\widehat{\partial}$, lateral view. - c. End of abdomen, $\hat{o}$, lateral view. - d. Epiphallus. - e. Body,, , lateral view. $-\mathrm{f}$. Krauss' organ, $\delta$. Abbreviations: $\mathrm{pp}=$ posterior projection, $\mathrm{mp}=$ median projection.

both sides. Male subgenital plate brown, in female blackish brown.

Measurements (in mm). Length of body: $\hat{\sigma}$ 26.7, + 34.5; pronotum: $\widehat{\delta} 11.1$, +13.5 ; tegmen: ô 5.1, q 7.1; hind femur: đo 13.4, q 18.1 . China.

Distribution. Endemic to Hebei Province of

Etymology. The specific epithet is named for Hebei, the type locality.

\subsection{A key to the genera of the tribe Haplotropidini}

1 Median keel of pronotum raised, but not arclike; posterior projections of epiphallus lon- ger than median projection; male cerci with attenuated apex; length of Krauss' organ 2.2 times width of its mid-part (Fig. 2a-d) Haplotropis

- Median keel of pronotum strongly arc-like (Figs.1b, e, 21). Posterior projections of epiphallus distinctly shorter than median projection (Figs. 1d, 2i). Male cerci conical (Figs. $1 \mathrm{c}, 2 \mathrm{~g})$. Length of Krauss' organ 1.4-1.7 times width of mid-part (Figs. 1f, 2h)

2. Median keel of pronotum entire, anterior margin of pronotum reaching hind margin of eye, abdomen with small teeth along median keel (Fig. 2f); frontal ridge not widened at median ocellus (Fig. 2e) 

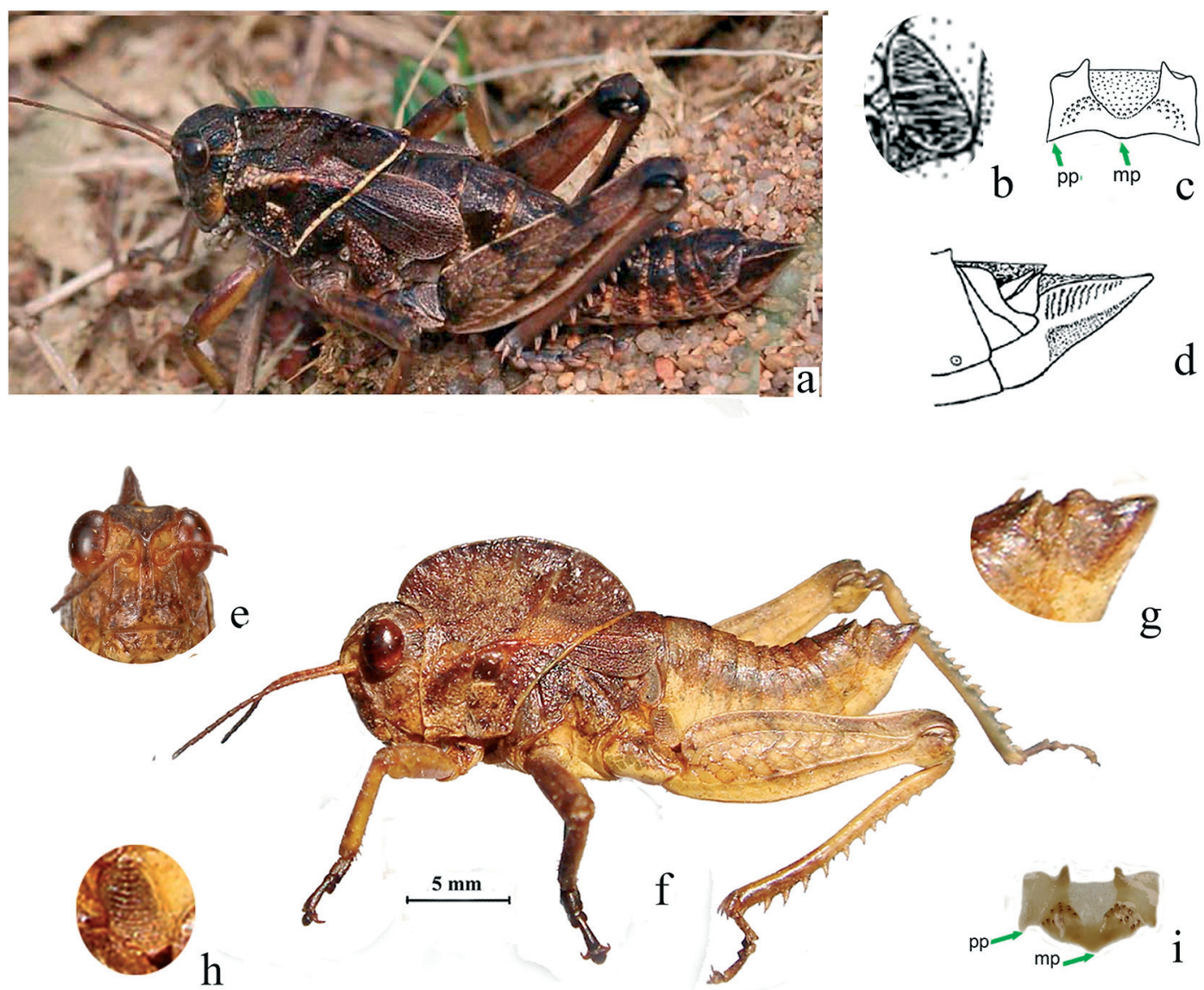

Fig. 2. Haplotropis brunneriana Saussure, 1888, $\widehat{\partial}$ (after Storozhenko \& Paik 2011) (a-d) and Humphaplotropis taishanensis Xiao, Yin et Yin, 2013, holotype ô (after Xiao et al. 2013) (e-i). - a. Body, lateral view. - b. Krauss' organ. - c. Epiphallus. - d. End of abdomen. - e. Head, frontal view. - f. Body, lateral view. - g. End of abdomen. - h. Krauss' organ. - i. Epiphallus. Abbreviations as in Fig. 1.

- Median keel of pronotum deeply cut by hind sulcus, anterior margin of pronotum not reaching hind margin of eye, abdomen with large teeth along median keel (Fig. 1b, e.); frontal ridge widened at median ocellus (Fig. 1a)

Sulcohumpacris gen. $\mathbf{n}$.

Acknowledgements. This study was funded by the National Natural Science Foundation of China (No. 31372153) and Scientific Research Projects of Hebei Higher Institutions for High-level Personnel (No. GCC2014001. We thank Mr. Ge Yan-Zhen for collecting the type specimens. We are also grateful to Dr. S. Yu. Storozhenko (Vladivostok, Russia) for the kind opportunity to duplicate some figures from his paper in the present work.

\section{References}

Bei-Bienko, G. J. \& Mistshenko, L. L. 1951: Locusts and grasshoppers in the fauna of the USSR and adjacent countries. Part. I: 328 . - Keys to the fauna of the USSR (38). 379 pp. [In Russian.]

Dong, L. J., Shi, J. P., Zhang, X. H., Zhang, Y. L., Li, X. J. \& Yin, H. 2015: Molecular phylogenetic analysis of Acridoidea (Orthoptera: Caelifera) based on mitochondrial cytochrome oxidase subunit sequences. Zootaxa 4018(3): 411-425.

Eades, D. C., Otte, D., Cigliano, M. M. \& Braun, H. 2015: Orthoptera Species File Online. Version 5.0/5.0. [2015.05]. [www document]. URL http://Orthoptera.SpeciesFile.org.

Li, X. J., Zhi, Y. C., Yin, Z., Liu, H. X. \& Yin, X. C. 2013: The complete mitochondrial genome of Humphaplotropis culaishanensis sp. nov. (Orthoptera: Acridoidea: Pamphagidae: Pamphaginae). — Mitochondrial DNA (2013) 878910 Online 1-2. 
Li, X. J., Cao, C. Q. \& Yin, X. C. 2014: A new species of the genus Humphaplotropis (Orthoptera: Pamphagidae: Pamphaginae) from Shandong, China. - Entomotaxonomia 36(1): 15-17.

Otte, D. 1994: Orthoptera Species File 3, Grasshoppers (Acridomopha) B, Pamphagoidea. - The Orthopterists' Society and The Academy of Natural Sciences of Philadelphia, Pennsylvania. pp. 142-206.

Saussure, H. de 1888: Additamenta ad prodromum Oedipodiorum. - Mémoires de la Société de physique et d'histoire naturelle de Genève. XXX No. 1: 122, 125.

Storozhenko, S. Y. \& Paik, J. C. 2011: Review of the genus Haplotropis Saussure, 1888 (Orthoptera: Pamphagidae), with notes on classification of the subfamilies Pamphaginae and Trinchinae. — Zootaxa 2897: 2734.

Xia, K. L., Bi, D. Y., Jin, X. B., Chen, Y. L., Li, H. C., Liu, J. P., Yin, X. C., Zheng, Z. M., Xi, G. S., Lian, Z. M., You, Q. J., Zhang, F. L. \& Li, T. S. 1994: Fauna Sinica. Insecta Vol. 4 (Orthoptera: Acridoidea: Pamphagidae, Chrotogonidae, Pyrgomorphidae). - Sciences Press. 340 pp.

Xiao, Y. L., Yin, Z. \& Yin, X. C. 2013: A new genus and species of grasshopper from China (Orthoptera:
Pamphagidae, Pamphaginae). - Acta Zootaxonomica Sinica 38(1): 87-89.

Yin, X. C., Shi, J. P. \& Yin, Z. 1996: A synonymic catalogue of grasshoppers and their allies of the world (Orthoptera: Caelifera). — China Forestry Publishing House, Beijing. 318 pp.

Zhi, Y. C., Shi, J. P. \& Dai, L. 2015: Two new species and key to four species of the genus Humphaplotropis from China (Orthoptera: Pamphagidae, Pamphaginae). - Zootaxa 4032(1): 134-140.

Zhang, D. C., Han, H. Y., Yin, H., Li, X. J., Yin, Z. \& Yin, X. C. 2011: Molecular Phylogeny of Pamphagidae (Acridoidea, Orthoptera) from China Based on Mitochondrial Cytochrome Oxidase II Gene. - Insect Science 18: 234-244.

Zhang, D. C., Li, X. J., Wang, W. Q., Yin, H., Yin, Z. \& Yin, X. C. 2006: Molecular phylogeny of some genera of Pamphagidae (Acridoidea, Orthoptera) from China based on mitochondrial 16S rDNA sequences. - Zootaxa 1103: 41-49.

Zhang, D. C., Yin, H. \& Yin, X. C. 2003: On the taxonomic system of Eurasian Pamphagidae (Orthoptera: Caelifera). - Acta Entomologica Sinica 46(2): 218-221. 